\title{
ANODIC STRIPPING VOLTAMMETRIC DETERMINATION OF LEAD USING A CHEMICALLY MODIFIED ELECTRODE BASED ON AZA CROWN ETHER
}

\author{
RODRIGO SEGURA*, KARINA DÍAZ, JAIME PIZARRO, ALAN PLACENCIO, \\ DIEGO TAPIA AND ÁNGELO FAJARDO
}

Departamento de Química de los Materiales, Facultad de Química y Biología, Universidad de Santiago de Chile (USACH), Casilla 40, Correo 33, Santiago, Chile.

A glassy carbon electrode was modified by drop-coating technique using 1,4,10,13-Tetraoxa-7,16-diazaciclooctadecano (diaza-18 -crown-6 or DA18C6) and Nafion (NF) for the determination of $\mathrm{Pb}$ (II) by square wave anodic stripping voltammetric (SWASV). The new electrode exhibits an increase in due to major

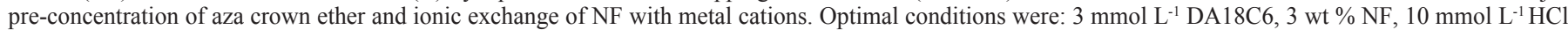
as supporting electrolyte, a frequency of $15 \mathrm{~Hz}$, an accumulation time of $300 \mathrm{~s}$ and an accumulation potential of $-0.80 \mathrm{~V}$. The detection limit was $0.09 \mu \mathrm{g} \mathrm{\textrm {L } ^ { - 1 }}$ and linear range was $10-50 \mu \mathrm{g} \mathrm{L}^{-1}$. Interference from metal ions such us $\mathrm{Fe}$ (II), $\mathrm{Pb}$ (II), Cd (II) and $\mathrm{Cu}$ (II) was also studied. The method is sensitive, selective and simple with a relative standard deviation of $11 \%$.

Keywords: Aza crown ether; anodic stripping voltammetry; lead.

\section{INTRODUCTION}

Lead is a non-degradable, bioaccumulative and toxic metal present in aqueous systems (rivers, lakes, sea, etc.) due to natural sources and anthropogenic factors causing adverse effects on the environment and on humans ${ }^{1-4}$. The World Health Organization (WHO) and the U.S. Environmental Protection Agency (EPA) have set a maximum level of 50 and $10 \mu \mathrm{g} \mathrm{L}^{-1}$ in seawater and drinking water, respectively ${ }^{5,6}$. Therefore, analytical methodologies to determine trace levels of this element are required ${ }^{7}$. Consequently, many analytical methods have been developed to determine $\mathrm{Pb}$ (II): atomic absorption spectrometry $(\mathrm{AAS})^{8,9}$, inductively coupled plasma mass spectrometry (ICP-MS) ${ }^{10-13}$, and atomic fluorescence spectrometry $(\mathrm{AFS})^{14,15}$. Although these techniques are selective and have high sensitivity, they are somewhat time-consuming, expensive and not allow in situ measurement. Electroanalytical techniques like anodic stripping voltammetry (ASV), cathodic stripping voltammetry (CSV) and adsorptive stripping voltammetry (AdSV) have important advantages including high sensitivity, accuracy and precision, as well as the low cost of instrumentation ${ }^{6,16-19}$. ASV is based on prior reduction of the analyte on a suitable working electrode by potential controlled preconcentration and subsequent electrochemical oxidation of the preconcentrate species. For decades, due to several electrochemical advantages, mercury electrodes have been widely used in stripping analysis, however due to their toxicity, their use is being restricted, emerging as alternative chemically modified electrodes (CMEs) with bismuth ${ }^{20}$, platinum, gold and nanomaterials ${ }^{21,22}$, among others CMEs have also attracted considerable interest for direct analysis of natural water samples, by modification of the surface or bulk matrix material of the electrode with a selected reagent (organic compounds, monomeric or polymeric). One of the widespread techniques in preparing CMEs consists of applying polymer films to the surface of the electrodes ${ }^{23,24}$. An alternative to modifiers are aza crown ether compounds due to host-guest interaction allowing selective interaction with metal ions through electrostatic interactions and by encapsulation in its cavity. This selective interaction is attributed to the ion size, the cavity and nature of the ion polarization in different solvents $\mathrm{s}^{25,26}$ Several studies detect some heavy metals using this kind of compounds ${ }^{27-30}$.

The aim of this work is the preparation of a chemically modified electrode using NF-DA18C6-GC that combines the selective complexing ability of the 1,4,10,13-Tetraoxa-7,16-diazaciclooctadecano (DA18C6) and the exchange properties of Nafion, using drop coating for the determination of $\mathrm{Pb}$ (II) by SWASV. The method was validated using certified reference waters (SPSWW1 and TDMA 53.1) and was applied to the analysis of the natural water.

2.

EXPERIMENTAL

\subsection{Apparatus}

Electrochemical experiments were carried out with a $\mathrm{CH}$ Instruments (USA) model $620 \mathrm{C}$ potentiostat. A three-electrode system consisting of a working glassy carbon electrode (CHI104, 3 mm diameter), $\mathrm{Ag} / \mathrm{AgCl}$ reference electrode $(3 \mathrm{~mol} \mathrm{~L}-1 \mathrm{KCl})$, and a platinum wire auxiliary electrode set up in a 10 $\mathrm{mL}$ electrochemical cell.

\subsection{Reagents}

All the reagents used were analytic grade: Nafion perfluorinated polymer ( $5 \mathrm{wt} \%$ solution in mixture of lower aliphatic alcohol and water), 1,4,10,13-Tetraoxa-7,16-diazaciclooctadecano (Diaza-18-Crown-6 or DA18C6) (Sigma Aldrich), acetic acid $\left(\mathrm{CH}_{3} \mathrm{COOH}\right)$, hydrochloric acid $(\mathrm{HCl})$ phosforic acid $\left(\mathrm{H}_{3} \mathrm{PO}_{4}\right)$, nitric acid $\left(\mathrm{HNO}_{3}\right)$, ethanol $\left(\mathrm{CH}_{3} \mathrm{CH}_{2} \mathrm{OH}\right)$, standards of $\mathrm{Pb}$ (II), Ni (II), Co (II), Fe (II), Cu (II), Cd (II) from $1000 \mathrm{mg} \mathrm{L}^{-1}$ (Merck).

\subsection{Procedure}

\subsubsection{Preparation of NF-DA18C6-GC electrode}

The glassy carbon electrodes were polished mechanically using $0.3 \mu \mathrm{m}$ alumina with double-distilled water on a porous surface. Then, they were rinsed and sonicated for 15 minutes in double-distilled water. The threeelectrode electrochemical cell was washed continuously with a $0.5 \mathrm{~mol} \mathrm{~L}^{-1}$ $\mathrm{HNO}_{3}$ solution. Using the drop coating technique, $10 \mu \mathrm{L}$ of a $0.1 \mathrm{~mol} \mathrm{~L}^{-1}$ with different Diaza-18-Crown-6 and Nafion (wt \%) ratios in ethanol were applied on the surface of the glassy carbon electrode drying it at $40{ }^{\circ} \mathrm{C}$ temperature. The modified electrodes were evaluated using SWASV.

\section{RESULTS AND DISCUSSION}

\subsection{Voltammetry characterization}

The electrochemical response of $50 \mu \mathrm{g} \mathrm{L}^{-1}$ of $\mathrm{Pb}$ (II) under unoptimized conditions $\left(\mathrm{C}_{\mathrm{DA18C}} 1 \mathrm{mmol} \mathrm{L}^{-1}\right.$, supporting electrolyte $\mathrm{CH}_{3} \mathrm{COOH} 10 \mathrm{mmol} \mathrm{L}^{-1}$, accumulation time $(\mathrm{t})$ of $180 \mathrm{~s}$ and an accumulation potential $(\mathrm{E})$ of -1.10 $\mathrm{V})$ was evaluated using ASV. Figure 1 shows the electrochemical behavior of GC, NF-GC and NF-DA18C6-GC. The oxidation signal of Pb (II) in GC is observed to $-0.45 \mathrm{~V}$, whereas NF-GC and NF-DA18C6-GC has a signal shift to $-0.65 \mathrm{~V}$. This signal shift towards more negative potentials is attributed to the complex formation DA18C6-Pb (II). The increase in current of $0.44 \mu \mathrm{A}$ with GC to $0.90 \mu \mathrm{A}$ with NF-DA18C6-GC is attributed to the formation of a complex type host-guest between DA18C6 and $\mathrm{Pb}(\mathrm{II})^{31,32}$, where the diameter of the ion $\mathrm{Pb}$ (II) is $2.4 \AA$ and the cavity DA18C6 is $2.6-3.2 \AA$. On the other hand, sulfonate groups of NF allow the accumulation of $\mathrm{Pb}$ (II) on the electrode surface $^{33,34}$.

\subsection{Effect of experimental variables}

The effect of supporting electrolyte (Figure 2) using $\mathrm{CH}_{3} \mathrm{COOH}, \mathrm{HCl}$ and $\mathrm{H} \mathrm{PO}$ was evaluated. It was found that there is an increase in the peak current associated with the oxidation of $\mathrm{Pb}(0)$ to $\mathrm{Pb}$ (II) with $\mathrm{HCl}$ due to its higher conductivity associated with its complete dissociation. Therefore, $\mathrm{HCl}$ was chosen for further studies. 


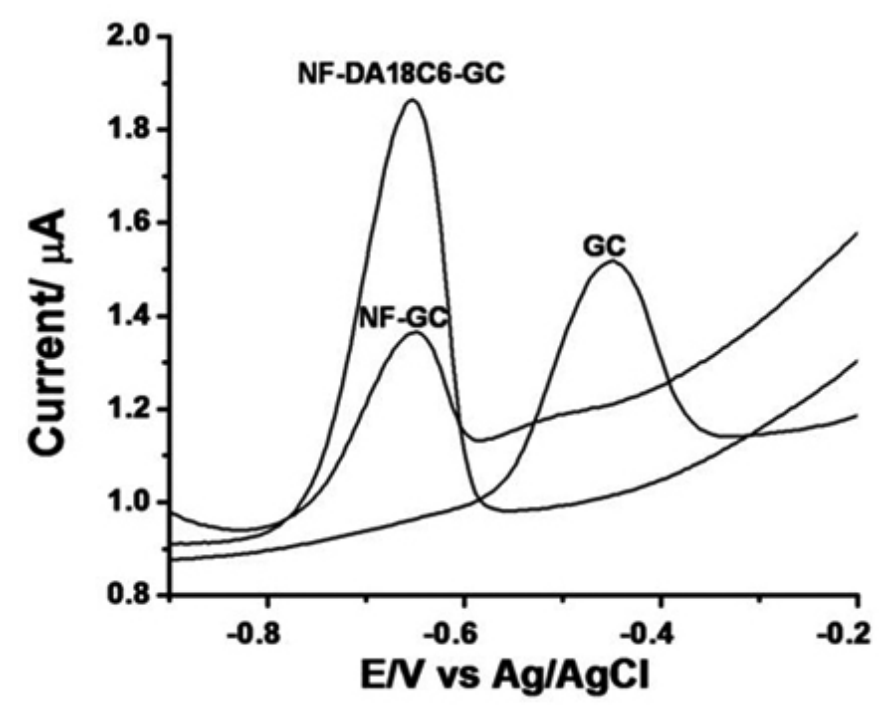

Figure 1. SWASV voltammograms of $50 \mu \mathrm{g} \mathrm{L} \mathrm{L}^{-1}$ of $\mathrm{Pb}$ (II) using: GC, NF-GC and NF-DA18C6-GC at $\mathrm{E}_{\text {acc }}-1.10 \mathrm{~V}, \mathrm{t}_{\text {acc }} 180 \mathrm{~s}$ and $15 \mathrm{~Hz}$ in $10 \mathrm{mmol}$ $\mathrm{L}^{-1} \mathrm{CH}_{3} \mathrm{COOH}$.

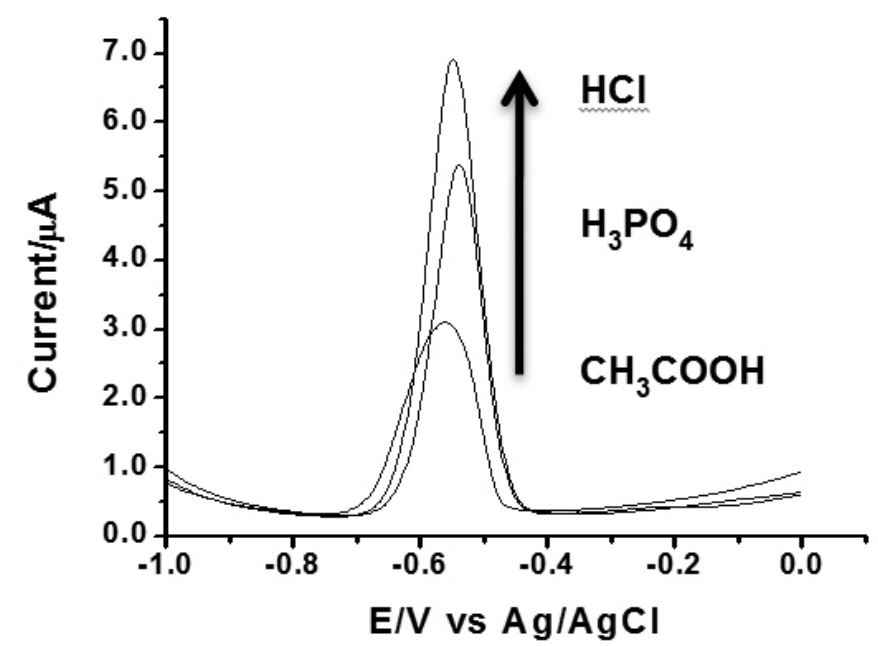

Figure 2. Effect of supporting electrolyte using $10 \mathrm{mmol} \mathrm{L}^{-1} \mathrm{HCl}$, $\mathrm{CH}_{3} \mathrm{COOH}$ and $\mathrm{H}_{3} \mathrm{PO}_{4}$ of $50 \mu \mathrm{g} \mathrm{L} \mathrm{L}^{-1}$ of $\mathrm{Pb}$ (II) with NF-DA18C6-GC at $\mathrm{E}_{\text {acc }}$ $-1.10 \mathrm{~V}, \mathrm{t}_{\text {acc }} 180 \mathrm{~s}$ and $15 \mathrm{~Hz}$.

The Figure 3 (a) shows the effect of the concentration of DA18C6 as modifying agent in the peak current of $50 \mu \mathrm{g} \mathrm{L} \mathrm{L}^{-1} \mathrm{~Pb}$ (II). It is observed that the peak current of $\mathrm{Pb}$ (II) increased and reached a maximum at $5 \mathrm{mmol}$ $\mathrm{L}^{-1}$ DA18C6; subsequently the concentration of crown does not produce a significant increase in the peak current, attributable to the saturation of active sites on the electrode surface or to the higher proportion of DA18C6 in the modifying solution, producing a film rupture ${ }^{33,35}$. To avoid separation of the film and to obtain the best analytical signal, a concentration of $3 \mathrm{mmol} \mathrm{L}^{-1}$ of DA18C6 was selected.

Figure 3 (b) shows the effect of Nafion concentration on the peak current of $50 \mu \mathrm{g} \mathrm{L}^{-1} \mathrm{~Pb}$ (II), which was evaluated between 0.5 and $5 \mathrm{wt} \%$ in $10 \mathrm{mmol}$ $\mathrm{L}^{-1} \mathrm{HCl}$ and a constant concentration of $3 \mathrm{mmol} \mathrm{L}^{-1}$ of DA18C6. The peak current of $\mathrm{Pb}$ (II) increases until reaching a maximum at $3 \mathrm{wt} \%$ and then it decreased. Similar results have been reported. This response can be explained by the fact that thick Nafion film displayed large cracks due to contractive force within the film. Through these openings in the polymer structure, the oxidized species can diffuse away from the electrode surface before significant replating occurs, inhibiting the redox cycling mechanism ${ }^{35}$. Therefore, 3 wt $\%$ Nafion solution was selected as the optimized condition.

On the other hand, Figure 3 (c) shows the effect of the accumulation potential between 0.00 and $-1.20 \mathrm{~V}$ in the presence of $50 \mu \mathrm{gL}^{-1}$ of $\mathrm{Pb}$ (II). The peak current increases when the reduction potential becomes more negative, however, at potentials lower than $-1.20 \mathrm{~V}$, the reduction of the proton to hydrogen ${ }^{36}$ begins at the electrode and hydrogen bubbles could produce detachment of the film and reduce the signal $\mathrm{Pb}$ (II). Based on these results, the optimum accumulation potential is $-0.80 \mathrm{~V}$.

Figure 3 (d) shows the effect of accumulation time on the peak current of $50 \mu \mathrm{g} \mathrm{L}^{-1}$ of $\mathrm{Pb}$ (II) between 60 and 1,500 s. The current increases with the accumulation time reaching a maximum in $900 \mathrm{~s}$. After this time, the current signal remains constant due to the saturation of active sites on the electrode surface.The accumulation time in the first stage of SWASV is directly related to the concentration of analyte, thus for low concentrations $\left(\sim 1-10 \mu \mathrm{g} \mathrm{L}^{-1}\right)$, it requires longer time than for higher concentrations of analyte, where it requires less time to saturate the electrode surface. A time of $300 \mathrm{~s}$ was selected for both for further studies. 
The effect of frequency of SWASV on $50 \mu \mathrm{L} \mathrm{L}^{-1}$ of $\mathrm{Pb}$ (II) was evaluated between 5 and $60 \mathrm{~Hz}$ (Figure $3 \mathrm{f}$-g). The peak current of oxidation of $\mathrm{Pb}$ to $\mathrm{Pb}$ (II) increases with frequency, but the signal is affected by a widening, losing definition. The frequency should not affect the reproducibility of the signal, so it is not recommended to use values above $30 \mathrm{~Hz}$. A frequency of $15 \mathrm{~Hz}$ was chosen as the optimum because clear and well defined currents peaks are obtained, with good sensitivity ${ }^{37}$.
3.3 Calibration data and application to real samples

The analytical method was developed under the following conditions: $\mathrm{E}_{\text {acc }}$ : $-0.80 \mathrm{~V}, \mathrm{t}: 300 \mathrm{~s}$, and a frequency of $15 \mathrm{~Hz}$. The measurements were made with successive additions of aliquots of $\mathrm{Pb}$ (II) solution with increments of about $10.0 \mu \mathrm{g} \mathrm{L}^{-1}$. Figure 4 (a) shows the voltammograms and (b) calibration curve obtained under the optimum parameters. The linear range is 10 to $50 \mu \mathrm{g}$ $\mathrm{L}^{-1}$ with a limit of detection (LOD) of $0.09 \mu \mathrm{gL}^{-1}$ with a confidence level of $95 \%$ and a Pearson coefficient of $0.996^{38}$.
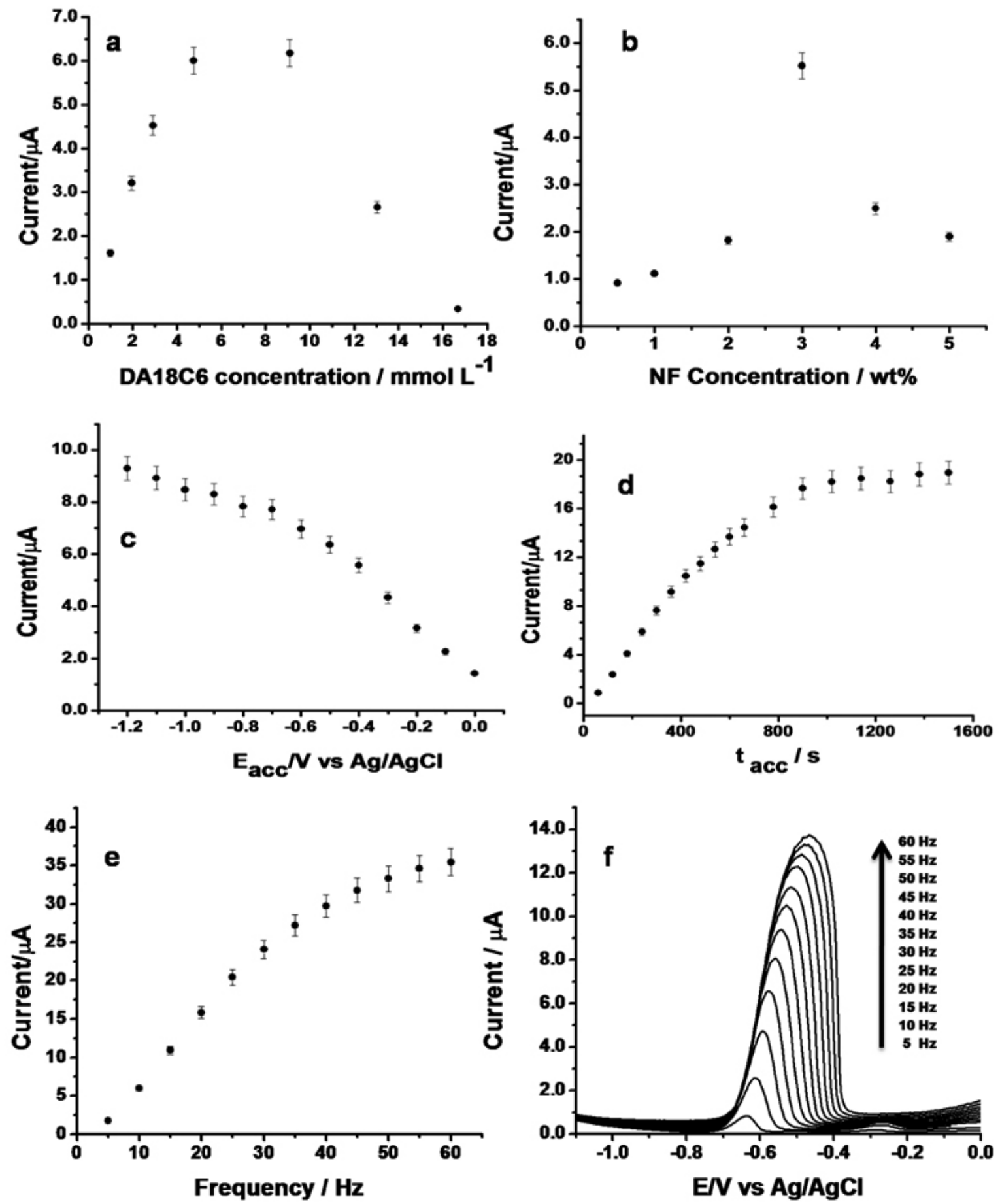

Figure 3. Effect of (a) DA18C6 concentration, (b) NF concentration, (c) accumulation potential, (d) accumulation time and (e-f) frequency in $50 \mu \mathrm{g} \mathrm{L}^{-1} \mathrm{~Pb}$ (II) in $10 \mathrm{mmol} \mathrm{L}^{-1} \mathrm{HCl}$. 

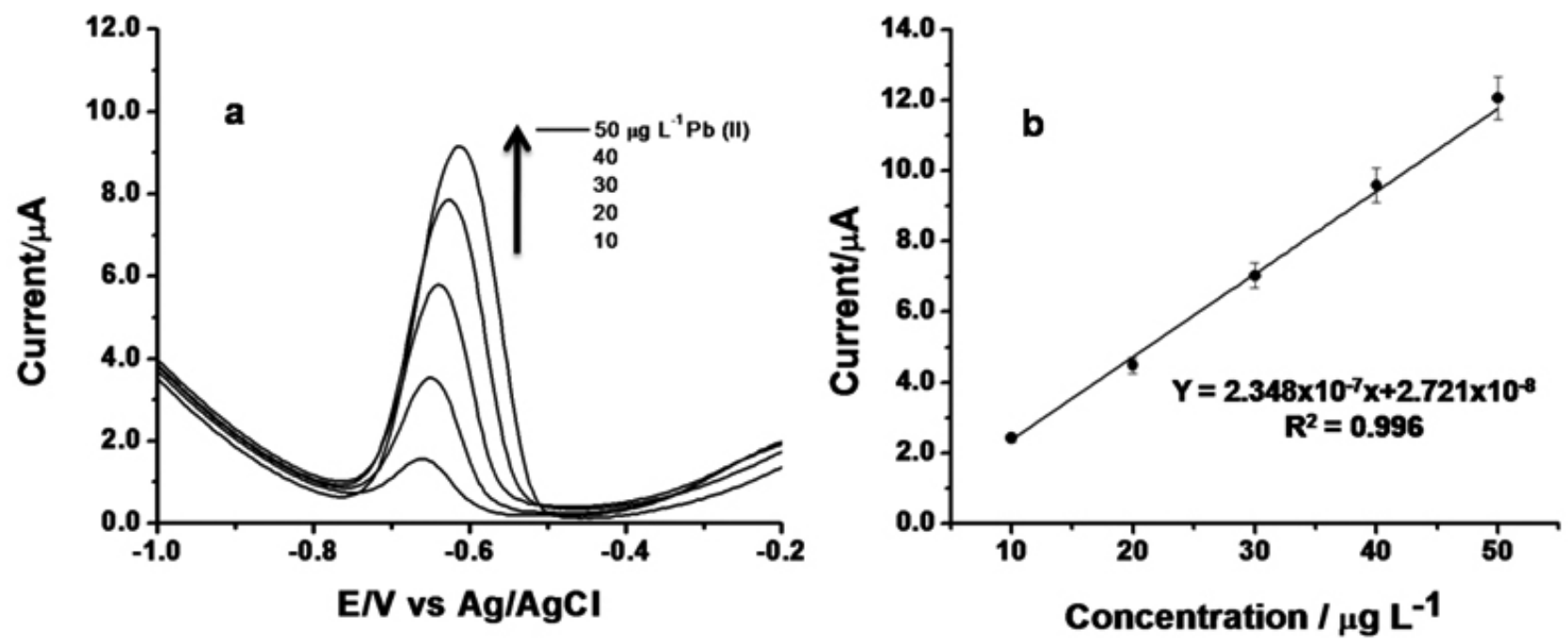

Figure 4. (a) Square wave stripping voltammograms and (b) calibration curves for $\mathrm{Pb}$ (II) using NF-DA18C6-GC at $10 \mathrm{mmol} \mathrm{L}^{-1} \mathrm{HCl}_{1} \mathrm{E}_{\text {acc }}-0.80 \mathrm{~V}$, $\mathrm{t}_{\mathrm{acc}} 300 \mathrm{~s}$, and $15 \mathrm{~Hz}$.

To evaluate the accuracy of the developed method, it was tested using a certified reference material TMDA-15 (11 $\mu \mathrm{g} \mathrm{L}^{-1}$ of $\left.\mathrm{Pb}(\mathrm{II})\right)$. Experimentally, a concentration of $11 \pm 0.67 \mu \mathrm{g} \mathrm{L}$ ( $\left.^{-1}=6\right)$ was found, obtaining a relative error of $6.72 \%$. No significant differences between the theoretical and experimental values were found. The repeatability was studied using a synthetic sample with $10 \mu \mathrm{g} \mathrm{L}^{-1}$ of $\mathrm{Pb}$ (II) evaluated in quadruplicate, finding a RSD of $10.19 \%$.

Reproducibility was evaluated using a standard solution of $10 \mu \mathrm{g} \mathrm{L}^{-1}$ of $\mathrm{Pb}$ (II) with three different electrodes. Analysis was developed by quadruplicate using the method of standard addition. The deviation found was less than $18 \%$. Based on these results, the proposed methodology is precise.

The results obtained using DA18C6-NF-GC were compared with different electrochemical sensors used in the determination of $\mathrm{Pb}$ (II). It is noted that DA18C6-NF-GC shows a similar response in terms of linearity range and detection limit compared to another electrodes (Table 1).

Table 1: Selected published data for the application of different electrodes in the stripping voltammetry of $\mathrm{Pb}$ (II).

\begin{tabular}{|c|c|c|c|c|c|}
\hline ElectrodeType & Mode & LinealRange & Detection limit & Matrix & Ref. \\
\hline $\begin{array}{c}\text { N-p-Chlorophenylcinnamo- } \\
\text { hydroxamic Acid Modified } \\
\text { Carbon Paste Electrode }\end{array}$ & DPASV & $2 \times 10^{-8}-1 \times 10^{-6} \mathrm{mmolL}^{-1}$ & $1 \times 10^{-8} \mathrm{mmolL}^{-1}$ & Potable water & 39 \\
\hline AgSPE & SWASV & $5-80 \mu \mathrm{gL}^{-1}$ & $0.46 \mu \mathrm{gL}^{-1}$ & $\begin{array}{c}\text { Pond Water, } \\
\text { Groundwater }\end{array}$ & 40 \\
\hline AuSPE & SWASV & $0-50 \mu \mathrm{gL}^{-1}$ & $0.50 \mu \mathrm{gL}^{-1}$ & River water & 41 \\
\hline NF-DC18C6 & ASV & $1 \times 10^{-9}-1 \times 10^{-7} \mathrm{mmolL}^{-1}$ & $5 \times 10^{-5} \mathrm{mmolL}^{-1}$ & Standard solution & 33 \\
\hline DA18C6-NF-GC & SWASV & $10.0-50.0 \mu \mathrm{gL}^{-1}$ & $0.09 \mu \mathrm{gL}^{-1}$ & River water & $\begin{array}{c}\text { This } \\
\text { work }\end{array}$ \\
\hline
\end{tabular}

\subsection{Interference}

The possible interference of metal ions: $\mathrm{Co}$ (II), Ni (II), Fe (II), Zn (II) As (II) and Se (IV) were studied in the presence of $30 \mu \mathrm{g} \mathrm{L}{ }^{-1} \mathrm{~Pb}$ (II) under optimized conditions. The change of signal current of lead was less than 10 $\%$ with the addition of 60 and $300 \mu \mathrm{g} \mathrm{L}-1$ of these ions. Based on these results, these ions were not considered as interference. On the other hand, with the addition of $60 \mu \mathrm{g} \mathrm{L}-1 \mathrm{Cd}$ (II) and $\mathrm{Cu}$ (II) two signal currents of these ions at -0.892 and $-0.156 \mathrm{~V}$ appeared respectively, however, none of these signals affected the signal of lead.

\subsection{Real Samples}

The optimized method was applied for the determination of $\mathrm{Pb}$ (II) in two water samples taken from two different places of Mapocho river: Farfana $\left(33^{\circ} 28^{\prime} 49,70^{\prime \prime} \mathrm{S} 70^{\circ} 48^{\prime} 41,00^{\prime \prime} \mathrm{W}\right)$ and Melipilla $\left(33^{\circ} 36^{\prime} 19,40^{\prime} \mathrm{S}\right.$ y $70^{\circ} 54^{\prime} 37$, 60 " W).The presence of lead was detected by ICP-OES and SWASV. The samples were fortified with $20 \mu \mathrm{g} \mathrm{L}^{-1}$ of $\mathrm{Pb}$ (II). The results of ICP-OES and SWASV with recovery $(\%)$ are present in Table 2 . The percent recovery obtained is within the accepted range, implying that the methodologies developed can be used as an alternative to the spectroscopic analysis.

Table 2. Analysis of real samples using ICP-OES and SWASV.

\begin{tabular}{|c|c|c|c|}
\hline $\begin{array}{c}\text { Sample } \\
(\mathrm{n}=6)\end{array}$ & $\begin{array}{c}\text { Concentration } \\
\text { ICP-OES } \\
\left(\mu \mathrm{g} \mathrm{L}^{-1}\right)\end{array}$ & $\begin{array}{c}\text { Concentration } \\
\text { SWASV } \\
\left(\mu \mathrm{g} \mathrm{L}^{-1}\right)\end{array}$ & $\begin{array}{c}\text { Recovery } \\
(\%)\end{array}$ \\
\hline Melipilla & 19.8 & $19.5(\% 5.1)$ & 97.5 \\
\hline La Farfana & 19.6 & $18.8(\% 6.3)$ & 94 \\
\hline
\end{tabular}




\section{CONCLUSIONS}

This method was successfully used for the determination of $\mathrm{Pb}$ (II) by SWASV using NF-DA18C6-GC under optimized parameters: supporting electrolyte $\mathrm{HCl} 10 \mathrm{mmol} \mathrm{L}^{-1}$, a concentration of $3 \mathrm{mmolL}^{-1}$ of DA18C6 and $3 \mathrm{wt} \%$ of Nafion, using $\mathrm{E}_{\text {acc }}-0.80 \mathrm{~V}, \mathrm{t}_{\mathrm{scc}} 300 \mathrm{~s}$. The proposed methodology is precise and accurate with a $\%$ RSD less than $21 \%$, with a linear range of $10-50$ $\mu \mathrm{g} \mathrm{L}^{-1}$ with a detection limit of $0.09 \mu \mathrm{g} \mathrm{L}^{-1}$

\section{ACKNOWLEDGMENTS}

The authors thank to FONDECYT, Chile for financial support under project $\mathrm{N}^{\circ} 1140206$ and "Dirección de Investigación Científica y Tecnológica (DICYT), Universidad de Santiago de Chile.

\section{REFERENCES}

1.- Gama, E. M.; Lima, A. D.; Lemos, V. A. Journal of Hazardous Materials 2006, 136, 757-762.

2.- Wong, E. L. S.; Chow, E.; Gooding, J. J. Electrochemistry Communications 2007, 9, 845-849

3.- Tuzen, M.; Soylak, M.; Parlar, K. Bulletin of Environmental Contamination and Toxicology 2005, 75, 284-289.

4.- Castaneda, M. T.; Perez, B.; Pumera, M.; del Valle, M.; Merkoci, A.; Alegret, S. Analyst 2005, 130, 971-976.

5.- Süren, E.; Yilmaz, S.; Türkoglu, M.; Kaya, S. Environmental Monitoring and Assessment 2007, 125, 91-98.

6.- Arancibia, V.; Nagles, E.; Cornejo, S. Talanta 2009, 80, 184-188

7.- da Silva, E. L.; Ganzarolli, E. M.; de Queiroz, R. R. U. Analytical Letters 2005, 38, 2089-2101.

8.- Fayazi, M.; Taher, M. A.; Afzali, D.; Mostafavi, A.; Ghanei-Motlagh, M. Materials Science and Engineering C 2016, 60, 365-373.

9.- Mohd Salim, R.; Khan Chowdhury, A. J.; Rayathulhan, R.; Yunus, K.; Sarkar, M. Z. I. Desalination and Water Treatment 2016, 57, 303-314.

10.- Chattopadhyay, P.; Fisher, A. S.; Henon, D. N.; Hill, S. J. Microchimica Acta 2004, 144, 277-283.

11.- Cerutti, S.; Silva, M. F.; GÃ jsquez, J. A.; Olsina, R. A.; Martinez, L. D. Spectrochimica Acta Part B: Atomic Spectroscopy 2003, 58, 43-50.

12.- Nakagawa, J.; Tsuchiya, Y. Japanese Journal of Toxicology and Environmental Health 1995, 41, 116-126.

13.- Lu, Y. Y.; Luo, D. G.; Lai, A.; Huang, X. X. In Water Resources and Environment - Proceedings of the International Conference on Water Resources and Environment, WRE 2015, 2016, pp 115-118.

14.- Beltrán, B.; Leal, L. O.; Ferrer, L.; Cerdà, V. Journal of Analytical Atomic Spectrometry 2015, 30, 1072-1079.

15.- Talio, M. C.; Alesso, M.; Acosta, M. G.; Acosta, M.; Fernández, L. P. Talanta 2014, 127, 244-249.

16.- Murray, R. W.; Ewing, A. G.; Durst, R. A. Analytical Chemistry 1987, 59, 379A-390A.

17.- Segura, R.; Pradena, M.; Pinto, D.; Godoy, F.; Nagles, E.; Arancibia, V. Talanta 2011, 85, 2316-2319.

18.- Arrigan, D. W. M. Analyst 1994, 119, 1953-1966.

19.- Ryan, M. D.; Chambers, J. Q. Analytical Chemistry 1992, 64, 79R-116R.

20.- Hutton, E. A.; Hocevar, S. B.; Ogorevc, B.; Smyth, M. R. Electrochemistry Communications 2003, 5, 765-769.

21.- Gumpu, M. B.; Sethuraman, S.; Krishnan, U. M.; Rayappan, J. B. B. Sensors and Actuators B: Chemical 2015, 213, 515-533.

22.- Shaidarova, L. G.; Budnikov, G. K. Journal of Analytical Chemistry 2008, 63, 922-942.

23.- Rahman, M. A.; Won, M.-S.; Shim, Y.-B. Analytical chemistry 2003, 75 1123-1129.

24.- Gouveia-Caridade, C.; Pauliukaite, R.; Brett, C. Electroanalysis 2006, 18 , 854-861.

25.- Gokel, G. W.; Leevy, W. M.; Weber, M. E. Chemical reviews 2004, 104, 2723-2750.

26.- Hiraoka, M. Crown ethers and analogous compounds; Elsevier, 2013.

27.- González-Calabuig, A.; Guerrero, D.; Serrano, N.; del Valle, M. Electroanalysis $\mathbf{2 0 1 5}$.

28.- Serrano, N.; González-Calabuig, A.; del Valle, M. Talanta 2015, 138, 130137.

29.- Prabhu, S. V.; Baldwin, R. P.; Kryger, L. Electroanalysis 1989, 1, 13-21.

30.- Anandhakumar, S.; Mathiyarasu, J. Microchimica Acta 2013, 180, 1065 1071.
31.- Parham, H.; Zargar, B. Russian Journal of Electrochemistry 2002, 38, 484-487.

32.- Alizadeh, N.; Shamsipur, M. Talanta 1993, 40, 503-506.

33.- Dong, S.; Wang, Y. Talanta 1988, 35, 819-821.

34.- Dong, S.; Wang, Y. Analytica Chimica Acta 1988, 212, 341-347.

35.- Torma, F.; Kádár, M.; Tóth, K.; Tatár, E. Analytica chimica acta 2008 $619,173-182$

36.- Segura, R.; Pizarro, J.; Díaz, K.; Placencio, A.; Godoy, F.; Pino, E.; Recio, F. Sensors and Actuators B: Chemical 2015, 220, 263-269.

37.- Wang, J. Analytical electrochemistry; John Wiley \& Sons, 2006.

38.- Miller, J. N. M.; Miller, J. C. J. N.; Miller, J. C.; Miller, J. N. M.; Miller, J. C. J. N.; Miller, J. C. M.; Miller, J. N. J. C.; Miller, J. N. Estadística y quimiometría para química analítica; Pearson Educación, 2002.

39.- Degefa, T. H.; Chandravanshi, B. S.; Alemu, H. Electroanalysis 1999, 11, 1305-1311.

40.- Zen, J.-M.; Yang, C.-C.; Kumar, A. S. Analytica Chimica Acta 2002, 464, 229-235.

41.- Laschi, S.; Palchetti, I.; Mascini, M. Sensors and Actuators B: Chemical 2006, 114, 460-465. 